\title{
Dystonia due to Bee Sting: A Case Report
} Arı Sokması Sonrası Distoni: Olgu Sunumu

Ali Karakuş, Koca Çalışkan, Mehmet Duru, Güven Kuvandık, Gökhan Arslan, Yakup Kadri Erdoğan, Mustafa Şahan

Department of Emergency Medicine, Faculty of Medicine, Mustafa Kemal University, Hatay, Turkey

\section{ABSTRACT}

Introduction: Dystonia is anabnormal contraction due to primary and secondary causes of the muscles in the body.

Case Report: In the literature, although many cases of congenital or edynsel with dystonia have been reported, a case as a result of a bee sting has not.

Conclusion: We aimed to present a case with recurrent dystonia as a result of a bee sting.

Keywords: Dystonia, bee sting, biperiden

Received: 16.02.2013 Accepted:09.07.2013

\section{ÖZET}

Giriş: Distoni, birincil ve ikincil nedenlere bağlı olarak gelişebilen vücuttaki kasların anormal kasılması durumudur.

Olgu Sunumu: Literatürde, doğuştan veya sonradan distoni gelişen birçok olgu bildirilmesine rağmen, arı sokması sonucu sadece bir olgu bildirilmiştir.

Sonuç: Biz de arı sokması sonucu tekrarlayan distoni gelişen olguyu sunmayı amaçladık.

Anahtar Kelimeler: Distoni, arı sokması, biperiden

Geliş Tarihi: 16.02.2013 Kabul Tarihi: 09.07.2013

\section{Giriş}

Beyindeki inhibitör ara nöron kusuru ve dopaminerjik aktivite anormallikleri sonucu geliştiği belirtilen distoniler, parkinson hastalığından sonra en sık görülen hareket bozukluğudur. Distoniler, başlangıç yaşı, anatomik yapı ve etyolojilerine göre gruplara ayrılmaktadır. Anatomik tutulumuna göre yaygın veya fokal olarak seyreden distoniler mevcuttur. Etyolojik olarak doğuştan veya sonradan oluşabilir. Primer distoniler genelde hareketle, sekonder olanlar ise istirahatte başlar. Tedavi bu ayırım yapıldıktan sonra altta yatan nedene yönelik olmaktadır. Distonilerin demiyelinizasyonla seyreden hastalık grubunda belirtilen arı sokması gibi nedenler sonucu oluştuğu da belirtilmiş ve literatürde tek olgu sunulmuştur (1). Arı venomu içerdiği enzimler nedeniyle bölgesel ve sistemik yan etkilere neden olmakta, nörotoksik etkisi miyelin kılıf harabiyetiyle gerçekleşmektedir. Venomun multipl skleroz ve parkinson gibi hastalıkların tedavilerinde kullanıldığını belirten çalışmalar da mevcuttur $(2,3)$. Biz de nadir nedenler arasında sayılan böyle bir olgu ile literatüre katkı sağlamayı amaçladık.

\section{Olgu Sunumu}

Onsekiz yaşında erkek hasta 2 gün önce boynundan arı sokması sonrası, olaydan 4 saat sonra kollarında ve boynunda kasılma şikâyetiyle dış merkeze başvurmuş. Medikal tedavi uygulanan hasta şikâyetleri düzelince taburcu edilmiş. Ancak ertesi gün şikâyetlerin tekrarlaması üzerine üniversitemiz acil servisine başvurdu.

Hastanın geldiğinde genel durumu iyi, şuuru açık koopere, tansiyonu: 110/85 mm/Hg, nabız: 95/dk, ateş: 36, $7^{\circ} \mathrm{C}$, solunumu: 16/ dk, oksijen satürasyonu: \%100 idi. Boynunda ve kollarında yaygın distonik ve koreiform hareketler mevcuttu (Resim 1). Diğer nörolojik muayene, göz dibi bakısı ve sistem muayeneleri normaldi. Hastanın hikâyesinde benzer bozukluklar, ilaç kullanım öyküsü ve intihar girişimi yoktu. Soygeçmişinde özellik saptanmadı. Laboratuar sonuçlarında anormallik saptanmadı. Elektrokardiyografisinde patolojik bulgu bulunmayan hastanın diğer distoni ayırıcı tanısı için çekilen kontrastsız beyin tomografisi ve beyin magnetik rezonans görüntülemeleri de normaldi. Hastaya $10 \mathrm{mg} / g u ̈ n$ biperidene lactate ( $2 \times 1$ dozunda intravenöz uygulama), 120 mg/gün pheniramine maleate (3x1 dozunda infüzyon yoluyla) başlandı. Acil gözlem odasında 2 gün takip edilen hastanın klinik tablosunda ve kontrol laboratuar değerlerinde anormallik saptanmadı. Biperiden ve pheniramine maleate ile taburcu edilen hastanın iki hafta boyunca takipleri ve kontrolu normaldi. 


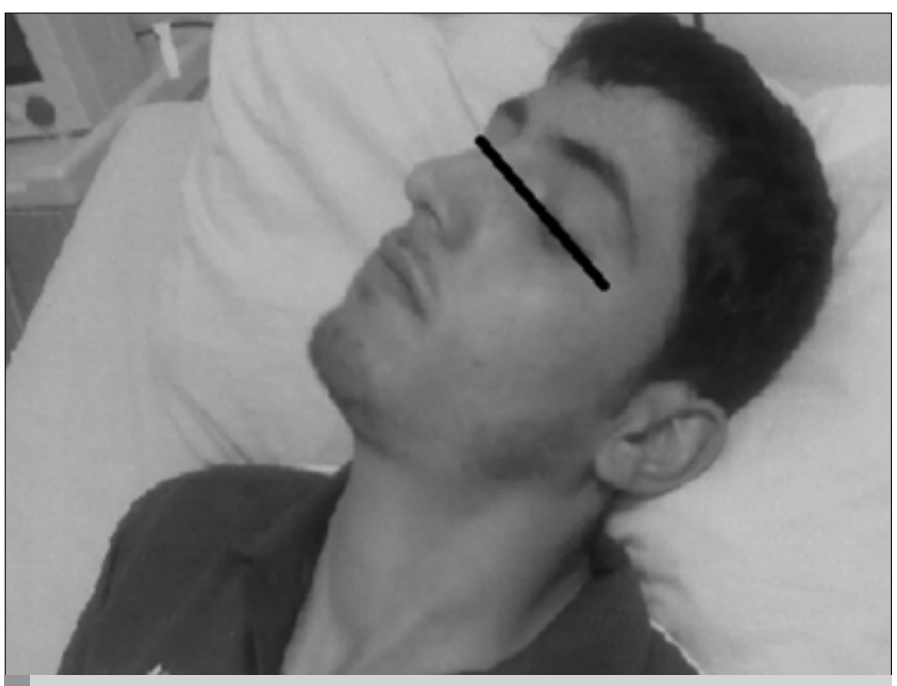

Resim 1. Fokal servikal distoni ve retrokollis

\section{Tartışma}

Distoniler etyolojik nedenlerine göre doğuştan veya sonradan gelişebilmektedir. Primer distoniler içinde genetik ve sporadik formlar, sekonder tip içinde ise distoni artı sendromlar, parkinsonizm, depo hastalıkları, multipl skleroz, elektrik çarpmaları, toksinler (karbonmonoksit, siyanür, metanol), travma, tümörler ve ilaçlar belirtilmektedir. Yapılan çalışmalarda ilaçlardan en sık dopamin agonistleri, antikonvulsanlar ve metoklopramid suçlanmaktadır (4-6). Arı sokmaları sonucu distonik reaksiyon gelişimi demiyelinizasyonla seyreden hastalık grubunda otoimmün olarak kabul edilmekte literatürde de tek bir olgu bildirilmektedir (1). Bizim olgumuzda daha önceden herhangi bir şikâyeti olmayan, ilaç kullanım veya hastalık öyküsü olmayan, hikâyesinde boyun bölgesinden arı sokması olan hasta idi. Ayırııı tanı için yapabildiğimiz tetkiklerin normal olduğu hastamızda arı sokmasına ikincil akut distoni geliştiği düşünüldü.

Hayvanlar âleminin alt grubu olan eklem bacaklılar (artropoda) içinde sınıflandırılan zarkanatılar (hymenoptera) takımı insanlara zarar veren en önemli böcek grubundadır. Tüm arı va yaban arıları bu gruba girmektedir (7). Arı venomu içerdiği histamin, fosfolipaz, hiyaluronidaz, minimin, apamin, mellitin, biyojenik aminler, lipidler ve amino asidler nedeniyle bölgesel (ağrı, kaşıntı, şişlik, kızarıkık) ve sistemik (alerjik reaksiyonlar, anjioödem, gastrointestinal, solunumsal, kardiak ve nörolojik sistem) şikayetlere ve ani ölümlere neden olabilmektedir (8). Mellitin, fosfolipaz, hiyaluronidaz asıl zehirli proteinlerdir. Apamin proteini ise spinal kord üzerine etkili olduğu söylenen nörotoksindir (7). Arı venomu iş̧̧i arılar tarafından ömrü boyunca (4-5 hafta), 0,3 mg kadar üretilerek zehir deposunda depolanıp salınır. Bu dozun hepsi arı tarafından ısırılan kişiye boşaltılırsa ölüme neden olabilmektedir. Klinik zehirlenme derecesi; sokma sayısı, anatomik bölge, arının türü, kişinin boyut ve duyarlılığına bağlıdır. Sistemik reaksiyonlar sıklıkla birçok arı tarafından ısıııldığında görülmektedir (7). Takip edilen olgu tek arı tarafından boyun bölgesinden sokulmuştu. Hastada bölgesel olarak ağıı, kızarıkık, kaşıntı gibi şikâyetlerinin yanında her iki kolda kasılma ve seyirmeler, boyun bölgesinde kasılma, tutukluk ve geriye doğru çekilme şikâyetleri olmuştu. Hastanın ilk değerlenmesinde üst ekstremitede tonik klonik tarzı kasılmaları, retrokollisi mevcuttu.
Distoni tedavisinde öncelikle altta yatan neden belirlenip ona yönelik tedavi planlanmaktadır. Dopaminerjik ilaçlar, antidopaminerjik tedavi (haloperidol, pimozid), antikolinerjikler (biperiden, triheksifenidil), benzodiyazepinler, baklofen, lidokain tedavide kullanılmakta ayrıca botilinum nörotoksininin de tedavi seçenekleri arasında olduğu belirtilmektedir (9). Cerrahi ve fizik tadavi uygulamaları da diğer tedavi yollarıdır. Dış merkezde yapılan tedaviye rağmen şikâyetleri tekrarlayan hastaya 10 mg/gün biperidene lactate, 120 mg/gün pheniramine maleate tedavisi uygulandı. Tedavi sonrası hastanın semptomları geriledi ve semptomsuz bir gün sonrasında şifa ile taburcu edildi.

\section{Sonuç}

Acil servislerde distoni ayırıcı tanısında nadir görülebilen arı sokmaları akla gelmelidir. Altta yatabilecek diğer hastalıkların tanısı için uygun tetkikler yapılarak yanlış tanı konulmamalıdır. Distonilerin takip ve tedavisi yeterli yapılmadığında tekrarlama eğiliminde olduğu unutulmamalıdır. Hastalar uygun takip ve tedavi sonrası semptomlar düzeldikten sonra taburcu edilmelidir.

Hasta Onamı: Yazılı hasta onamı bu çalışmaya katılan hastadan alınmıştır.

Hakem değerlendirmesi: Dış bağımsız.

Yazar Katkıları: Fikir-A.K.; Tasarım- A.K.; Denetleme- A.K.-M.Ş.; Kaynaklar- A.K.- K.Ç.; Malzemeler -K.Ç.-M.D.-G.K.-G.A.-Y.K.E.; Veri toplanması ve/veya işlemesi- K.Ç- Y.K.E.; Analiz ve/veya yorum- M.D.-G.K.; Literatür taraması- A.K- M.Ş.; Yazıyı yazan-A.K.; Eleştirel Innceleme- M.D.-G.K.

Çıkar Çatışması: Yazarlar herhangi bir çıkar çatışması bildirmemişlerdir.

Finansal Destek: Yazarlar bu çalışma için finansal destek almadıklarını beyan etmişlerdir.

Informed Consent: Written informed consent was obtained from the patient who participated in this study

Peer review: Externally peer-reviewed.

Author contributions: Concept - A.K.; Design - A.K.; Supervision A.K.-M.S.; Materials - K.Ç.-M.D.-G.K.-G.A.-Y.K.E.; Data Collection and/ or Processing - K.Ç-Y.K.E.; Analysis and/or Interpretation - M.D.-G.K.; Literature Review - A.K.- M.Ş.; Writer - A.K.; Critical Review - M.D.-G.K.

Conflict of interest: The authors declare no conflict of interest.

Financial Disclosure: The authors declared that this study has received no financial support.

\section{Kaynaklar}

1. Benito-Conejero S, López-Domínguez JM, Martínez-Marcos F, BlancoOllero A, Díaz-Espejo C, Pujol-De la Llave E. Acute dystonia following a wasp sting. Rev Neurol 2005; 41: 62-3.

2. Kim JI, Yang EJ, Lee MS, Kim YS, Huh Y, Cho IH, Kang S, Koh HK. Bee venom reduces neuroinflammation in the MPTP-induced model of Parkinson's disease. Int J Neurosci. 2011; 121: 209-17. [CrossRef] 
3. Çota S. Arı zehirinin hazırlanışı ve kullanım alanları. Uludağ Arıcılık Dergisi 2002; 4: 24-29.

4. Işıkay S, Almacıoğlu M, Yılmaz K. Bir Çocukta Metaklopramid'e Bağlı Akut Distonik Reaksiyon: Bir Olgu Sunumu. Akademik Acil Tıp Olgu SunumlarI Dergisi 2012; 3: 59-1.

5. Söğüt Ö, Kaya H, Solduk L, Dokuzoğlu MA. Metoklopramid Kullanımına Bağlı Gelişen Akut Distoni: Iki Olgu Sunumu. Akademik Acil Tıp Olgu Sunumları Dergisi 2011; 2: 50-3.
6. Sedat Işıkay, Kutluhan Yılmaz, Mehmet Almacıoğlu. Evaluation of Patients with Metoclopramide-Induced Acute Dystonic Reaction. The Journal Of Academıc Emergency Medıcıne 2013; 12: 80-4 [CrossRef]

7. Oktay C. Arı sokmaları. Satar S, Editör. Acilde Klinik Toksikoloji.1.Baskı. Adana: Nobel Kitabevi; 2009; s. 621-6.

8. Ciszowski K, Mietka-Ciszowska A. Hymenoptera stings. Przegl Lek. 2007; 64: 282-9.

9. Paus $\mathrm{S}$, Bigalke $\mathrm{H}$, Klockgether T. Neutralizing antibodies against botulinum toxin a after a wasp sting. Arch Neurol. 2006; 63: 1808-9. [CrossRef] 